\title{
Comparison of the severity of non-alcoholic fatty liver disease in diabetic and non-diabetic obese patients
}

\section{Comparação da gravidade da doença hepática gordurosa não alcoólica de pacientes obesos diabéticos e não diabéticos}

\author{
Paulo Roberto Ott-Fontes ${ }^{1}$; João Alfredo Diedrich Neto ${ }^{1}$; ; Marcos Bertozzi Goldoni ${ }^{1}$.
}

\begin{abstract}
A B S T R A C T
Introduction: nonalcoholic fatty liver disease presents a broad spectrum of histopathological alterations, from steatosis to liver cirrhosis. Patients with diabetes mellitus (DM) present increased incidence and severity of NAFLD. Objective: determine the prevalence and severity of NAFLD in diabetic and non-diabetic obese patients undergoing bariatric surgery. Method: the evaluation of liver biopsies was carried out through NAFLD activity score (NAS) in order to evaluate degree of hepatic steatosis, presence of ballooning, inflammatory activity and degree of fibrosis. Results: a total of 154 patients who have undergone bariatric surgery with intraoperative biopsy were observed and divided into two BMI ranges: from 35 to 44.9 and from 45 to 54.9. 32 (20.8\%) from 154 patients were diabetic and 122 (79.2\%) were nondiabetic. Patients with DM were significantly older than patients without the disease, presenting $41.29 \pm 9.40$ years vs $36.71 \pm 10.13$ years in the group with BMl of 35 to 44.9 ( $p=0.049)$; and $45.13 \pm 7.10$ years vs $37.00 \pm 9.24$ years in the group with BMl of 45 to 54.9 ( $p=0.024)$. In the histological evaluation, patients with DM from the BMI group of 35 to 44.9 had a strong association with higher prevalence and severity of steatosis, balloning, inflammation, fibrosis and steatohepatitis. Conclusion: the present study confirms the high prevalence of NAFLD in patients with Morbid Obesity. Prevalence and severity increase proportionally to BMl and who have DM as comorbidity.
\end{abstract}

Keywords: Non-alcoholic Fatty Liver Disease. Liver Cirrhosis. Diabetes Mellitus. Obesity, Morbid. Bariatric Surgery.

\section{INTRODUCTION}

$\mathrm{N}$ on-alcoholic fatty liver disease (NAFLD) is the accumulation of triglycerides in hepatocytes, which can lead to an increase in liver mass by $5-10 \%{ }^{1}$ in individuals with low alcohol consumption. It presents different degrees of histological alterations, divided into simple hepatic steatosis (HS) and nonalcoholic steatohepatitis (NASH), with the presence of inflammatory reaction, hepatocellular damage, ballooning of hepatocytes, with or without varying degrees of fibrosis², progressing to cirrhosis and hepatocellular carcinoma. NAFLD is the most common liver disorder in the world, with a reported prevalence of up to $35 \%^{3}$.
The main risk factors for NAFLD are the same as for the Metabolic Syndrome (MS): central obesity, dyslipidemia, and insulin resistance 4 . Thus, NAFLD is considered the hepatic component of MS, being an independent risk factor for the development of cardiovascular disease ${ }^{5}$.

The natural history of NAFLD is usually a reflection of the natural history of MS, especially due to their overlapping causes and physiopathology. Therefore, it is conceivable that their main complications are also similar. Cardiovascular disease, not liver disease, is thus the most common cause of death among patients with this condition.

Dyslipidemia and Insulin Resistance (IR) have a strong association with excessive deposition of

1 - Federal University of Health Sciences of Porto Alegre, Gastrointestinal Surgery - Porto Alegre - RS - Brazil 
triglycerides in hepatocytes ${ }^{6}$. This accumulation of lipid is associated with increased gluconeogenesis, decreased glycogen synthesis, which exacerbates IR and increases low-grade inflammation, leading to the progression of liver disease to fibrosis, cirrhosis, and increased risk of hepatocarcinoma?.

Weight loss is the most important factor in controlling NAFLD. The weight loss goal, when starting a diet with a caloric reduction of about $25 \%$, is approximately $10 \%$, although the need for weight loss varies according to the severity of the disease. The effects of bariatric surgery on NAFLD are related to improved histology, including resolution of NASH in $75 \%$ of cases, reduction of fibrosis in $35 \%$ of cases ${ }^{8}$, and partial reversion of cirrhosis ${ }^{9}$, effects achieved with no other treatment, including diet and habits changing.

In 2015, the International Diabetes Federation published data estimating the prevalence of type 2 diabetes (T2DM) in 415 million people and with a prospect of growth to 642 million by the year $2040^{10}$. Adequate glycemic control of T2DM is crucial in preventing complications, improving quality of life and reducing mortality ${ }^{11}$. However, even with new advances in clinical treatment, drug control is successful in less than $30 \%$ of patients ${ }^{12,13}$. In this context, bariatric surgery and metabolic surgery emerge as forms of control that go beyond weight loss, further improving metabolic control, with a consequent reduction in cardiovascular risk ${ }^{14}$. In Brazil, the issue was first addressed in 2006, with liver biopsies carried out during bariatric surgery, observing the prevalence of nonalcoholic steatohepatitis in 57.1\%, with improvement after gastric bypass ${ }^{15}$.

The aim of this study is to correlate the histological findings of liver biopsy performed during bariatric surgery of obese, diabetic and non-diabetic patients, grouped according to body mass index, to describe the clinical characteristics and to evaluate and compare the prevalence of HS, NASH and fibrosis.

\section{PATIENTS AND METHODS}

In this retrospective study, 228 obese, diabetic and non-diabetic patients who underwent bariatric surgery by the same team from the Irmandade Santa Casa de Misericórdia of Porto Alegre (ISCMPA), from
2016 to 2018, underwent perioperative liver biopsy. We excluded 74 patients due to reported alcohol consumption greater than $140 \mathrm{~g} /$ week for men and $70 \mathrm{~g} /$ week for women ${ }^{16}$, use of drugs or hepatotoxic medications, presence of other liver diseases, previous weight reduction procedures - previous bariatric surgery or intra-gastric balloon insertion. We assessed the remaining 154 patients using anthropometric data, body mass index (BMI), laboratory variables and histopathological variables. We considered patients with T2DM those already in treatment with insulin and oral antidiabetics in the preoperative evaluation, and those without treatment but with fasting glucose greater than $126 \mathrm{mg} / \mathrm{dL}$ and with glycosylated hemoglobin (HbA1c) >6.5 in consecutive analyzes ${ }^{17}$. We considered hypertensive patients those in antihypertensive use or with blood pressure $>130 / 85 \mathrm{mmHg}^{18}$. We divided the patients into two groups according to a BMl cutoff of $45 \mathrm{~kg} / \mathrm{m}^{2}$ and, subsequently, between diabetics and non-diabetics, to try to quantify the effects of obesity according to its evolution and the association with T2DM. The research was approved by the ISCMPA ethics committee (opinion 04887018.1.0000.5335).

We routinely performed the perioperative liver biopsy with laparoscopy cold scissors in the liver segment III through two confluent incisions forming a wedge, and later cauterized it with monopolar cautery. Although the choice of needle biopsy is the most common, surgical wedge biopsies had good accuracy and are cost effective if carried out are appropriately, with collection of satisfactory samples $(>10 \mathrm{~mm})^{19}$.

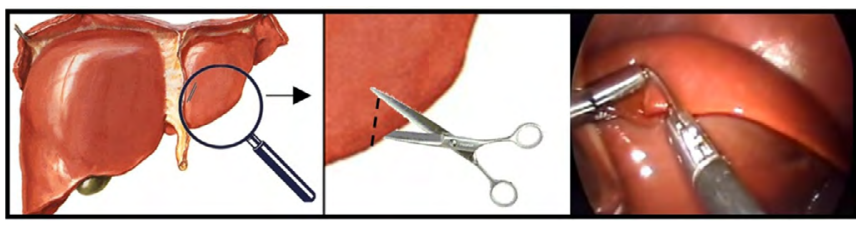

Figure 1. Método da biópsia hepática e aspecto transoperatório.

Different pathologists analyzed the liver biopsy spepcimens at the ISCMPA pathology service. The standard histopathological technique used for specimen analysis was the Perls and the Masson's trichrome. We used the NAFLD activity score (NAS) system, proposed by 
Kleiner ${ }^{20}$ and collaborators, to assess the degree of HS, the presence of ballooning, inflammation activity and the degree of fibrosis.

The NAS system evaluation involves setting scores to the histological analysis $\left(\begin{array}{ll}0 & 8\end{array}\right)$, the degree of steatosis $(0-3)$, lobular inflammation $(0-3)$ and ballooning $(0-2)$. The degree of fibrosis is assessed in the same, semi-quantitative way. The presence of less than $5 \%$ of steatosis receives 0 ; from $5 \%$ to $33 \%, 1$; from $34 \%$ to $66 \%, 2$; and greater than $66 \%, 3$. For the diagnosis of $\mathrm{NASH}$, there must be steatosis associated with hepatocyte ballooning and/or inflammatory infiltrate. NASH activity was classified according to the presence of ballooning as none (0), mild (1) or severe (2), and as to lobular inflammation, in none (0), 1-2 foci in 20 fields (1), 3-4 foci in 20 fields (2), and more than 4 foci in 20 fields (3).

We classified the degree of fibrosis as: stage 0 , without fibrosis; grade $1 \mathrm{a}$, when mild fibrosis was identified in zone 3 ; grade $1 \mathrm{~b}$, when moderate fibrosis was identified in zone 3; grade 1c, when only periportal/ portal fibrosis was identified; grade 2, when periportal/ portal fibrosis and zone 3 were identified; grade 3, when bridging fibrosis was identified; and grade 4, when cirrhosis was identified.

\section{STATISTICAL ANALYSIS}

In the descriptive analyzes, were expressed quantitative variables as mean \pm standard deviation (SD) and median, and the qualitative variables, as frequency and percentage. For comparison between patients with or without diabetes, we used the Student's t test or the Mann-Whitney test, according to the distribution of quantitative variables assessed by the Shapiro-Wilk normality test. For the other qualitative variables, we applied the chi- square test, stratifying by BMI (35 $44.9 \mathrm{~kg} / \mathrm{m} 2$ and $4554.9 \mathrm{~kg} / \mathrm{m} 2$ ). We adopted $\mathrm{p}<0.05$ as statistically significant. We performed all analyzes using the IMB® SPSS $®$ software version 23.0.

\section{RESULTS}

The average hospital stay was 4.3 days for the entire group. There was no report of any surgical complications (bleeding, biliary fistula) related to the liver biopsy.

Of the 154 patients, 32 (20.8\%) were diabetic and 122 (79.2\%), non-diabetic. Patients with T2DM were significantly older than patients without the condition, $41.29 \pm 9.40$ years vs $36.71 \pm 10.13$ years, in the group with a BMI of $3544.9 \mathrm{~kg} / \mathrm{m} 2(p=0.049)$ and $45.13 \pm 7.10$ years vs $37.00 \pm 9.24$ years in the group with a BMl of $4554.9 \mathrm{~kg} / \mathrm{m} 2$ ( $p=0.024)$. In addition, in this latter group there was a significant association of diabetes with the presence of systemic arterial hypertension (SAH) $(p=0.033)$, according to the data expressed in table 1.

Table 1. Anthropometric data and prevalence of SAH.

\begin{tabular}{lcccc}
\hline BMI & Variables & $\begin{array}{c}\text { Without } \\
\text { DM }\end{array}$ & With DM & p value \\
\hline & Age* $^{*}$ & $\begin{array}{c}36.71 \pm \\
10.13\end{array}$ & $\begin{array}{c}41.29 \pm \\
9.40\end{array}$ & 0.049 \\
$35-44.9$ & $\begin{array}{c}\text { Gender } \\
(\mathrm{M})\end{array}$ & $20(23.5)$ & $8(33.3)$ & 0.480 \\
& SAH (Y) & $28(32.9)$ & $14(58.3)$ & 0.033 \\
\hline & Age* & $37.00 \pm$ & $45.13 \pm$ & 0.024 \\
$45-54.9$ & $\begin{array}{c}\text { Gender } \\
\text { (M) }\end{array}$ & $10(27.0)$ & $5(62.5)$ & 0.095 \\
& SAH (Y) & $14(37.8)$ & $5(62.5)$ & 0.253
\end{tabular}

*Values expressed as mean \pm standard deviation.

The main surgical technique was the Rouxen-Y gastric bypass. In patients with BMI between 35 and $44.9 \mathrm{~kg} / \mathrm{m}^{2}$ without T2DM, 75 patients (88.2\%) underwent gastric bypass and 10 underwent sleeve gastrectomy (11.2\%). In patients with BMI between 45 and $54.9 \mathrm{~kg} / \mathrm{m}^{2}$ without T2DM, 34 (88.2\%) underwent gastric bypass and three (8.1\%) underwent sleeve gastrectomy. Of the patients with T2DM, both with a BMI between 35 and $44.9 \mathrm{~kg} / \mathrm{m}^{2}$ and those with a BMI between 45 and $54.9 \mathrm{~kg} / \mathrm{m}^{2}$ underwent gastric bypass.

We categorized the laboratory variables 
as normal or altered. According to the definition of metabolic syndrome, we considered, as altered values, total cholesterol $(\mathrm{TC})>200 \mathrm{mg} / \mathrm{dL}$, triglycerides (TG) $\geq 150 \mathrm{mg} / \mathrm{dL}$, and $\mathrm{HDL}$ cholesterol $<40 \mathrm{mg} / \mathrm{dL}$ for men and $<50 \mathrm{mg} / \mathrm{dL}$ for women. Patients with T2DM are more prone to alterations in such laboratory tests, although this association has not been statistically significant. Table 2 shows the data collected in the laboratory tests.

The histological evaluation, shown in Table 3 , indicates that patients with T2DM in the group with a BMI $35-44.9 \mathrm{~kg} / \mathrm{m}^{2}$ had increased prevalence and severity of HS, ballooning, inflammation, fibrosis and $\mathrm{NASH}$.
Table 2. Laboratory tests.

\begin{tabular}{|c|c|c|c|c|}
\hline $\mathrm{BMI}$ & Variables & Without DM & With DM & $p$-value \\
\hline \multirow{3}{*}{$35-44.9$} & $\begin{array}{c}\text { TC } \\
\text { (Altered) }\end{array}$ & $33(38.8)$ & $14(58.3)$ & 0.105 \\
\hline & $\begin{array}{c}\mathrm{HDL} \\
\text { (Altered) }\end{array}$ & $20(23.5)$ & $9(37.5)$ & 0.196 \\
\hline & $\begin{array}{c}\text { TG } \\
\text { (Altered) }\end{array}$ & 33 (38.8) & $12(50.0)$ & 0.355 \\
\hline \multirow{3}{*}{$45-54.9$} & $\begin{array}{c}\text { TC } \\
\text { (Altered) }\end{array}$ & $14(37.8)$ & $2(25.0)$ & 0.691 \\
\hline & $\begin{array}{c}\mathrm{HDL} \\
\text { (Altered) }\end{array}$ & $13(35.1)$ & $5(62.5)$ & 0.235 \\
\hline & $\begin{array}{c}\text { TG } \\
\text { (Altered) }\end{array}$ & $10(27.0)$ & $4(50.0)$ & 0.221 \\
\hline
\end{tabular}

Table 3. Histological evaluation of patients with BMl $35-44.9 \mathrm{~kg} / \mathrm{m}^{2}$.

\begin{tabular}{|c|c|c|c|c|}
\hline Variables & & Without T2DM & With T2DM & $p$ value \\
\hline \multirow[t]{5}{*}{ Steatosis } & & & & 0.003 \\
\hline & $<5 \%$ & $18(21.2)$ & $1(4.2)$ & \\
\hline & $5-33 \%$ & $27(31.8)$ & $3(12.5)$ & \\
\hline & $34-66 \%$ & $17(20.0)$ & $4(16.7)$ & \\
\hline & $>66 \%$ & $23(27.1)$ & $16(66.7)$ & \\
\hline \multirow[t]{4}{*}{ Ballooning } & & & & 0.006 \\
\hline & None & $32(37.6)$ & $1(4.2)$ & \\
\hline & Mild & $1(1,2)$ & $1(4.2)$ & \\
\hline & Severe & $52(62.1)$ & $22(91.7)$ & \\
\hline \multirow[t]{5}{*}{ Inflammation } & & & & 0.008 \\
\hline & None & $33(38.8)$ & $1(4.2)$ & \\
\hline & 1-2 foci per 20 fields & $38(44.7)$ & $15(62.5)$ & \\
\hline & $2-4$ foci for 20 fields & $13(15.3)$ & $8(33.3)$ & \\
\hline & $>4$ foci for 20 fields & $1(1,2)$ & $0(0.0)$ & \\
\hline \multirow[t]{4}{*}{ NAS } & & & & 0.001 \\
\hline & NASH Absent & $16(18.8)$ & $1(4.2)$ & \\
\hline & Borderline NASH & $32(37.6)$ & $2(8.3)$ & \\
\hline & NASH Present & $37(43.5)$ & $21(87.5)$ & \\
\hline \multirow[t]{6}{*}{ Fibrosis } & & & & 0.002 \\
\hline & F0 & $41(48.2)$ & $4(16.7)$ & \\
\hline & F1 & $31(36.5)$ & $9(37.5)$ & \\
\hline & F2 & $8(9.4)$ & $3(12.5)$ & \\
\hline & F3 & $4(4.7)$ & $7(29.2)$ & \\
\hline & F4 & $1(1,2)$ & $1(4.2)$ & \\
\hline Total & & 85 & 24 & \\
\hline
\end{tabular}


Table 4 shows data on the histological evaluation of patients with BMI $4554.9 \mathrm{~kg} / \mathrm{m}^{2}$, allowing to conclude that there was no statistically significant association of HS severity, ballooning degeneration, inflammation, fibrosis and NASH in patients with T2DM.

Table 4. Histological evaluation of patients with BMl $4554.9 \mathrm{~kg} / \mathrm{m}^{2}$

\begin{tabular}{|c|c|c|c|c|}
\hline Variables & & $\begin{array}{l}\text { Without } \\
\text { T2DM }\end{array}$ & $\begin{array}{l}\text { With } \\
\text { T2DM }\end{array}$ & $p$ value \\
\hline \multirow[t]{5}{*}{ Steatosis } & & & & 0.683 \\
\hline & $<5 \%$ & $2(5,4)$ & $0(0,0)$ & \\
\hline & $5-33 \%$ & $11(29,7)$ & $2(25,0)$ & \\
\hline & $34-66 \%$ & $13(35,1)$ & $2(25,0)$ & \\
\hline & $>66 \%$ & $11(29,7)$ & $4(50,0)$ & \\
\hline \multirow[t]{4}{*}{ Ballooning } & & & & 0.766 \\
\hline & None & $6(16.2)$ & $2(25.0)$ & \\
\hline & Mild & $1(2.7)$ & $0(0.0)$ & \\
\hline & Severe & $30(81.1)$ & $6(75.0)$ & \\
\hline \multirow[t]{5}{*}{ Inflammatioon } & & & & 0.701 \\
\hline & None & $6(16.2)$ & $2(25.0)$ & \\
\hline & $\begin{array}{r}1-2 \text { foci } \\
\text { per } 20 \\
\text { fields }\end{array}$ & $22(59.5)$ & $5(62.5)$ & \\
\hline & $\begin{array}{r}3-4 \text { foci } \\
\text { for } 20 \\
\text { fields }\end{array}$ & $9(24.3)$ & $1(12.5)$ & \\
\hline & $\begin{array}{r}>4 \text { foci } \\
\text { for } 20 \\
\text { fields } \\
\end{array}$ & $0(0.0)$ & $0(0.0)$ & \\
\hline \multirow[t]{4}{*}{ NAS } & & & & 0.754 \\
\hline & $\begin{array}{r}\text { NASH } \\
\text { Absent }\end{array}$ & $2(5.4)$ & $0(0.0)$ & \\
\hline & $\begin{array}{r}\text { Borderline } \\
\text { NASH }\end{array}$ & $11(29.7)$ & $3(37.5)$ & \\
\hline & $\begin{array}{r}\text { NASH } \\
\text { Present }\end{array}$ & $24(64.9)$ & $5(62.5)$ & \\
\hline \multirow[t]{6}{*}{ Fibrosis } & & & & 0.546 \\
\hline & FO & $11(29.7)$ & $4(50.0)$ & \\
\hline & $\mathrm{F} 1$ & $15(40.5)$ & $3(37.5)$ & \\
\hline & F2 & $6(16.2)$ & $0(0.0)$ & \\
\hline & F3 & $5(13.5)$ & $1(12.5)$ & \\
\hline & F4 & $0(0.0)$ & $0(0.0)$ & \\
\hline Total & & 37 & 8 & \\
\hline
\end{tabular}

\section{DISCUSSION}

In the present study, we evaluated 154 obese patients undergoing surgical treatment for obesity. First, we should mention that of these patients, 109 underwent gastric bypass, a classic technique for the treatment of obesity. Although sleeve gastrectomy is the growing preference in surgical technique, it is still a matter of discussion regarding the resolution of NAFLD ${ }^{21}$. Regarding weight loss, both techniques are effective in the short, medium and long term ${ }^{22}$.

Certainly, for some time NAFLD was regarded as morbidity associated with morbid obesity and without much importance in the long term. On the other hand, morbid obesity and metabolic syndrome have become epidemic, causing obesity surgery to take on the role of effective treatment. Currently, NAFLD has been deemed another component of MS and not simply a component of obesity ${ }^{23}$.

The physiopathology of liver injury in obese patients is controversial. Although there is a positive relationship between obesity and NAFLD, being overweight is not a necessary condition for its genesis. Patients with lipodystrophy, for example, have a high prevalence of IR, T2DM and hepatic steatosis, strengthening the hypothesis that not the amount of adipose tissue, but its dysfunction, is the major villain of NAFLD ${ }^{24}$. Thus, despite the positive relationship between obesity and NAFLD, the BMI and the patient's absolute weight are not directly related. Most of these patients display a clinical profile similar to those with $\mathrm{MS}^{25}$.

In lean sedentary patients, high consumption of free fatty acids (FFA) increases the availability of long-chain fatty acids in the liver, and this accumulation is able to promote liver inflammation. Although with strong association with obesity and IR, not all patients with NAFLD have these risk factors, showing the heterogeneity of the syndrome and suggesting a polycausal nature ${ }^{26}$.

In this study, when evaluating the demographic characteristics of groups of patients with BMls of 35 $44.9 \mathrm{~kg} / \mathrm{m}^{2}$ and $4554.9 \mathrm{~kg} / \mathrm{m}^{2}$, diabetic patients were in average older than non-diabetic ones. We also observed a positive relationship between diabetes and hypertension. Possibly, younger, obese, and not yet 
diabetic patients may be prone to develop diabetes and hypertension, as a pathophysiological sequence of the metabolic syndrome ${ }^{27}$.

Patients with T2DM are more prone to display alterations in laboratory markers for MS. Although this association has not been statistically significant, it is consistent with the literature.

NAFLD encompasses a wide spectrum of injuries, such as steatosis, steatohepatitis and fibrosis, and often one finds these three pathologies in the same patient. In the presence of fibrosis, progression to cirrhosis occurs in $20 \%$ of cases. Cirrhotic patients, on their turn, display $10 \%$ progression to hepatocarcinoma ${ }^{28}$.

The general prevalence of NAFLD in the present study was $86.36 \%$, compatible with the literature ${ }^{29}$, which reports prevalence between $84 \%$ and $96 \%$ of NAFLD in patients with morbid obesity. In the group of patients with BMI $3544.9 \mathrm{~kg} / \mathrm{m}^{2}$, non-diabetics had a prevalence of $78 \%$, and diabetics, $95.8 \%$. In the group of patients with BMI $4554.9 \mathrm{~kg} / \mathrm{m}^{2}$, non-diabetics had a prevalence of $94.6 \%$, and diabetics, $100 \%$. Thus, it is clear that the prevalence of NAFLD increases with BMI and it has a positive association with T2DM.

With regard specifically to inflammation, in the group of patients with BMI $3544.9 \mathrm{~kg} / \mathrm{m}^{2}$, the prevalence of inflammation diagnosed by biopsy was $95.83 \%$ in diabetic patients compared with $38.82 \%$ among non-diabetics. That is, even though obesity may be the triggering factor in the pathophysiology of NAFLD ${ }^{30}$, low-grade inflammation triggered by the association of obesity with insulin resistance will be more harmful than isolated obesity.

To perform a quantitative analysis of NAFLD, we used the NAFLD activity score (NAS) and the degree of fibrosis, which allowed for a more practical and objective assessment and comparison of the stages of liver disease between groups. In the group of patients with a BMI between $3544.9 \mathrm{~kg} / \mathrm{m}^{2}$, diabetic patients obtained a mean NAS of $5.6 \pm 1.5$, and non-diabetics, $3.6 \pm 2.3$, as shown in Graph 1. In the group of patients with BMI between $4554.9 \mathrm{~kg} / \mathrm{m}^{2}$, diabetic patients had a mean NAS of $4.6 \pm 1.9$, and non-diabetics, $4.6 \pm 1.7$, as recorded in Graph 2. There was statistical significance only in the group of patients with BMl $3544.9 \mathrm{~kg} / \mathrm{m}^{2}$, a fact that can be explained in two ways: 1 - The group of patients with BMI $4554.9 \mathrm{~kg} / \mathrm{m}^{2}$ has a reduced number of patients; 2 - The deleterious effect of morbid obesity in the patients with BMI $4554.9 \mathrm{~kg} / \mathrm{m}^{2}$ is much greater. These results corroborate the pro-inflammatory character of T2DM as a component of MS.

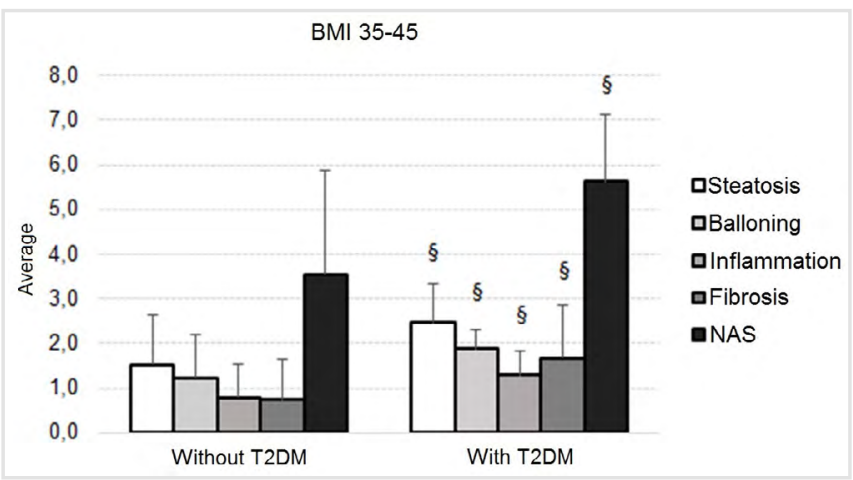

Graph 1. Histological evaluation in the group with a BMI of 35-44.9 $\mathrm{kg} / \mathrm{m}^{2}$. \& Differs significantly from those without T2DM (Mann-Whitney test; $p<0.05)$.

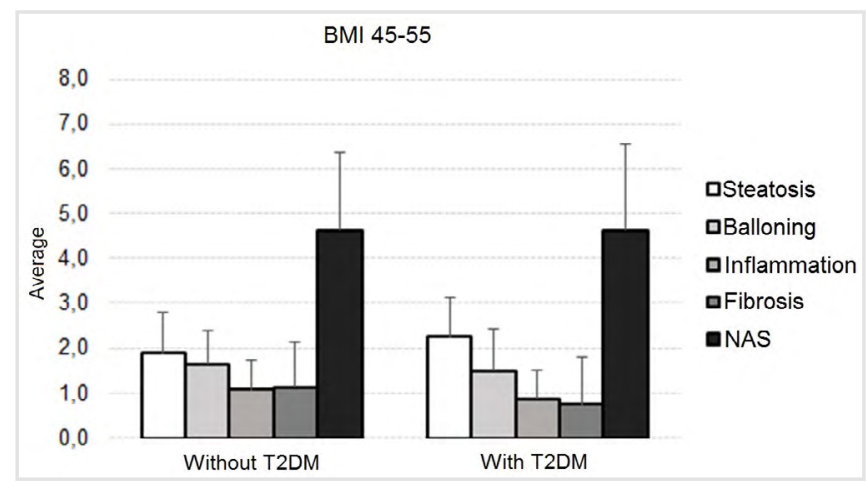

Graph 2. Histological assessment in the group with a BMl of $45-54.9 \mathrm{~kg} / \mathrm{m}^{2}$.

The retrospective nature of the study and the small number of diabetic patients in the group with BMI of $4554.9 \mathrm{~kg} / \mathrm{m}^{2}$ are possible limitations when analyzing our results.

In conclusion, our data confirm a high prevalence of NAFLD in patients with morbid obesity. The prevalence and severity of the disease increase in proportion to the BMI. Patients in the same BMI range that also have T2DM have higher prevalence and severity of the disease, demonstrating a strong association with MS, although not statistically significant for the group of patients with a BMI between 45 and $54.9 \mathrm{~kg} / \mathrm{m}^{2}$. 
R E S U M O

\begin{abstract}
Introdução: a doença hepática gordurosa não alcoólica apresenta um amplo espectro de alterações histopatológicas, desde a esteatose até a cirrose hepática. Pacientes com diabetes Mellitus (DMT2) têm risco aumentado para incidência e gravidade dessa doença. Objetivo: determinar a prevalência e a gravidade da DHGNA em pacientes obesos diabéticos e não diabéticos submetidos à cirurgia bariátrica. Pacientes e Métodos: avaliação das biópsias hepáticas através do NAFLD activity score (NAS) para avaliação quanto ao grau de esteatose hepática, à presença de balonização, à atividade da inflamação e ao grau de fibrose. Resultados: foram observados 154 pacientes submetidos à cirurgia bariátrica com biópsia transoperatória concomitante, divididos em duas faixas de IMC, de 35 a 44.9kg/m² e de 45 a 54.9kg/m². Dos 154 pacientes, 32 (20,8\%) eram diabéticos e 122 (79,2\%) eram não diabéticos. Os pacientes com DMT2 eram significativamente mais velhos, 41,29 $\pm 9,40$ anos vs 36,71 110,13 anos, no grupo com IMC de 35 a $44.9 \mathrm{~kg} / \mathrm{m}^{2}(p=0,049)$ e 45,13 $\pm 7,10$ anos vs 37,00 $\pm 9,24$ anos no grupo com IMC de 45 a 54.9kg/m² ( $\left.p=0,024\right)$. Na avaliação histológica realizada, os pacientes com DMT2 do grupo com IMC de 35 a 44.9 apresentaram forte associação com maior prevalência e gravidade de estetose, balonização, inflamação, fibrose e esteato-hepatite. Conclusão: os dados deste estudo confirmam prevalência elevada de DHGNA em pacientes com obesidade mórbida. A prevalência e a gravidade aumentam proporcionalmente ao IMC e com a presença de DMT2.
\end{abstract}

Palavras chave: Hepatopatia Gordurosa não Alcoólica. Cirrose Hepática. Diabetes Mellitus. Obesidade Mórbida. Cirurgia Bariátrica.

\section{REFERENCES}

1. Festi D, Colecchia A, Sacco T, Bondi M, Roda E, Marchesini G. Hepatic steatosis in obese patients: clinical aspects and prognostic significance. Obes Rev. 2004;5(1):27-42.

2. Chalasani N, Younossi Z, Lavine JE, Diehl AM, Brunt EM, Cusi $K$, et al. The diagnosis and management of non-alcoholic fatty liver disease: practice guideline by the American Association for the Study of Liver Diseases, American College of Gastroenterology, and the American Gastroenterological Association. Hepatology. 2012;55(6):2005-23.

3. Younossi ZM, Stepanova $M$, Afendy $M$, Fang $Y$, Younossi $\mathrm{Y}$, Mir $\mathrm{H}$, et al. Changes in the prevalence of the most common causes of chronic liver diseases in the United States from 1988 to 2008. Clin Gastroenterol Hepatol. 2011;9(6):524-30.

4. Singh S, Allen AM, Wang Z, Prokop LJ, Murad MH, Loomba R. Fibrosis progression in nonalcoholic fatty liver vs nonalcoholic steatohepatitis: a systematic review and meta-analysis of paired-biopsy studies. Clin Gastroenterol Hepatol. 2015;13(4):643-54.

5. Adams LA, Lymp JF, St Sauver J, Sanderson SO, Lindor KD, Feldstein A, et al. The natural history of nonalcoholic fatty liver disease: a population-based cohort study. Gastroenterology. 2005;129(1):11321.

6. Hafeez S, Ahmed MH. Bariatric surgery as potential treatment for nonalcoholic fatty liver disease: a future treatment by choice or by chance? J Obes.
2013;2013:839275.

7. Chitturi S, Abeygunasekera S, Farrell GC, HolmesWalker J, Hui JM, Fung $C$, et al. NASH and insulin resistance: insulin hypersecretion and specific association with the insulin resistance syndrome. Hepatology. 2002;35(2):373-9.

8. Lassailly G, Caiazzo R, Buob D, Pigeyre M, Verkindt $\mathrm{H}$, Labreuche J, et al. Effects of bariatric surgery on severe liver injury in morbid obese patients with proven NASH: a prospective study. Hepatology. 2014;60(Suppl):305A.

9. Kral JG, Thung SN, Biron S, Hould FS, Lebel S, Marceau S, et al. Effects of surgical treatment of the metabolic syndrome on liver fibrosis and cirrhosis. Surgery. 2004;135(1):48-58.

10. International Diabetes Federation. IDF Diabetes Atlas [Internet]. 7th ed. Brussels, Belgium: International Diabetes Federation; 2015 [revised 2017 Dec 12]. Available from: http://www.diabetesatlas.org

11. Mendes $A B$, Fittipaldi JA, Neves RC, Chacra AR, Moreira Jr ED. Prevalence and correlates of inadequate glycaemic control: results from a nationwide survey in 6,671 adults with diabetes in Brazil. Acta Diabetol. 2010;47(2):137-45.

12. Casagrande SS, Fradkin JE, Saydah SH, Rust KF, Cowie CC. The prevalence of meeting $A 1 C$, blood pressure, and LDL goals among people with diabetes, 1988-2010. Diabetes Care. 2013;36(8):2271-9.

13. Sumithran $P$, Prendergast $L A$, Delbridge $E$, Purcell $K$, Shulkes A, Kriketos A, et al. Long-term persistence of hormonal adaptations to weight loss. N Engl J Med. 
2011;365(17):1597-604.

14. Schauer PR, Burguera B, Ikramuddin S, Cottam D, Gourash W, Hamad G, et al. Effect of laparoscopic Roux-en $Y$ gastric bypass on type2 diabetes mellitus. Ann Surg. 2003;238(4):467-84.

15. Almeida SR, Savassi-Rocha PR, Sanches MD, Leite VHR, Silva RAP, Diniz MTC, et al. Roux-en-Y gastric bypass improves the nonalcoholic steatohepatitis (NASH) of morbid obesity. Obes Surg. 2006;16(3):270-8.

16. Cotrim HP, Daltro C. Liver: does bariatric surgery reduce the severity of NAFLD? Nat Rev Gastroenterol Hepatol. 2010;7(1):11-3.

17. International Expert Committee. International Expert Committee report on the role of the A1C assay in the diagnosis of diabetes. Diabetes Care. 2009;32(7):1327-34.

18. Eckel RH, Grundy SM, Zimmet PZ. The metabolic syndrome. Lancet. 2005;365(9468):1415-28.

19. Padoin AV, Mottin CC, Moretto M, Berleze D, Kupski C, Glock L, et al. A comparison of wedge and needle hepatic biopsy in open bariatric surgery. Obes Surg. 2006;16(2):178-82.

20. Kleiner DE, Brunt EM, Van Natta M, Behling C, Contos MJ, Cummings OW, Ferrell LD, Liu YC, Torbenson MS, Unalp-Arida A, Yeh M, McCullough AJ, Sanyal AJ; Nonalcoholic Steatohepatitis Clinical Research Network. Design and validation of a histological scoring system for nonalcoholic fatty liver disease. Hepatology. 2005;41(6):1313-21.

21. Angrisani L, Santonicola A, lovino P, Vitiello A, Zundel $N$, Buchwald $H$, et al. Bariatric surgery and endoluminal procedures: IFSO worldwide survey 2014. Obes Surg. 2017;27(9):2279-89.

22. Peterli $R$, Wölnerhanssen BK, Peters $T$, Vetter $D$, Kröll D, Borbély $Y$, et al. Effect of laparoscopic

Received in: 09/02/2019

Accepted for publication: 19/03/2020

Conflict of interest: no.

Funding source: none. sleeve gastrectomy vs laparoscopic Roux-en-Y gastric bypass on weight loss in patients with morbid obesity: the SM-BOSS randomized clinical trial. JAMA. 2018;319(3):255-65.

23. Marchesini G, Brizi M, Bianchi G, Tomassetti $S$, Bugianesi $E$, Lenzi $M$, et al. Nonalcoholic fatty liver disease: a feature of the metabolic syndrome. Diabetes. 2001; 50(8):1844-50.

24. Marchesini G, Bugianesi E, Forlani G, Cerrelli F, Lenzi $M$, Manini $R$, et al. Nonalcoholic fatty liver, steatohepatitis, and the metabolic syndrome. Hepatology. 2003;37(4):917-23.

25. Younossi ZM, Stepanova M, Negro F, Hallaji S, Younossi $Y$, Lam B, et al. Nonalcoholic fatty liver disease in lean individuals in the United States. Medicine (Baltimore). 2012;91(6):319-27.

26. Chitturi S, Abeygunasekera S, Farrell GC, HolmesWalker J, Hui JM, Fung $C$, et al. NASH and insulin resistance: insulin hypersecretion and specific association with the insulin resistance syndrome. Hepatology. 2002;35(2):373-9.

27. Bellentani S. The epidemiology of non-alcoholic fatty liver disease. Liver Int. 2017;37 Suppl 1:81-4.

28. Adams LA, Lymp JF, St Sauver J, Sandeson SO, Lindor KD, Feldsteinn $A$, et al. The natural history of nonalcoholic fatty liver disease: a population-based cohort study. Gastroenterology. 2005;129(1):11321.

29. Clark JM. The epidemiology of nonalcoholic fatty liver disease in adults. J Clin Gastroenterol. 2006;40 Suppl 1:S5-10.

30. Zangar RC, Novak RF. Effects of fatty acids and ketone bodies on cytochromes P450 2B, 4A, and 2E1 expression in primary cultured rat hepatocytes. Arch Biochem Biophys. 1997;337(2):217-24.

\section{Mailing address:}

João Alfredo Diedrich Neto

E-mail: joaodiedrich@gmail.com 